\title{
Peningkatan Hasil Belajar IPA melalui Metode Demonstrasi pada Siswa Kelas III SDI Tetandara, Kabupaten Ende
}

\author{
Arnesta Patrisia Wende ${ }^{1 *}$, Yuliani Sepe Wangge ${ }^{2}$, Finsensius Mbabho ${ }^{3}$ \\ 1,2,3 Program Studi PGSD Universitas Flores Ende. \\ Jalan Samratulangi, Kelurahan Pupire, Ende, Flores, Indonesia \\ * Corresponding Author: arnestawende651@gmail.com

\section{Info Artikel Abstract} \\ Sejarah Artikel: \\ Diterima : 11/12/2019 \\ Direvisi : 15/02/2020 \\ Disetujui :01/03/2020 \\ Keywords: \\ demonstration method, \\ learning outcomes \\ This research aims: (1) to know how to implement natural science learning with \\ demonstration method in grade III children in SDI Tetandara, Ende District. (2) To find out \\ the improvement of natural sciences through demonstration methods in grade III students at \\ SDI Tetandara, Ende District. The type of research used is class action research (CAR) and \\ the subject in the study was a grade III student in SDI Tetandara which amounted to 20 \\ people. Data collection techniques using observation techniques, tests, documentation and \\ interviews. Data is analyzed descriptively by calculating the average and percentage of the \\ submission in each cycle. Based on the results of data analysis and discussion of the results \\ shows that the use of demonstration methods has an influence on the outcome of learning \\ natural sciences, on material objects. This is evident from the teacher's ability to manage \\ student learning outcomes in the learning process. Visible from the Pretest result with an \\ average value obtained value of 48 . Then, the student's value increased from the cycle I study \\ results showed the average grade III value was 57 and was in the category enough and the \\ percentage was 35\%. In Cycle II Learning, the results gained increased by the percentage of \\ the compensation reached $100 \%$ with the average value gained 84.5. This value indicates an \\ increase in the results gained on cycle learning I. These results show that demonstration \\ methods can improve the results of natural Science study on students in class III in SDI \\ Tetandara District of Ende.
}

\begin{abstract}
Abstrak
Penelitian ini bertujuan: (1) Untuk mengetahui bagaimana pelaksanaan pembelajaran Ilmu Pengetahuan Alam dengan metode demonstrasi pada anak kelas III di SDI Tetandara Kabupaten Ende. (2) Untuk mengetahui peningkatan hasil belajar Ilmu pengetahuan alam melalui metode demonstrasi pada siswa kelas III di SDI Tetandara Kabupaten Ende. Jenis penelitian yang digunakan adalah Penelitian Tindakan Kelas (PTK) dan subyek dalam penelitian adalah siswa kelas III di SDI Tetandara yang berjumlah 20 orang. Teknik pengumpulan data menggunakan teknik observasi, tes, dokumentasi dan wawancara. Data dianalisis secara deskriptif dengan menghitung rata-rata dan persentase ketuntasan di setiap siklus. Berdasarkan hasil analisis data dan pembahasan hasil penelitian menunjukkan bahwa penggunaan metode demonstrasi mempunyai pengaruh terhadap hasil belajar Ilmu Pengetahuan alam, pada materi gerak benda. Hal ini terlihat dari kemampuan guru mengelola hasil belajar siswa pada proses pembelajaran. Terlihat dari hasil Pretest dengan nilai rata-rata diperoleh nilai 48. Kemudian, nilai siswa meningkat dari hasil belajar siklus I menunjukkan nilai rata-rata kelas III adalah 57 dan berada pada kategori cukup dan persentasenya adalah $35 \%$. Pada pembelajaran siklus II, hasil yang diperoleh semakin meningkat yaitu persentase ketuntasan mencapai $100 \%$ dengan nilai rata-rata yang diperoleh 84,5. Nilai ini menunjukkan adanya peningkatan dari hasil yang diperoleh pada pembelajaran siklus I. Hasil ini menunjukkan bahwa metode demonstrasi dapat meningkatkan hasil belajar Ilmu Pengetahuan Alam pada siswa di kelas III di SDI Tetandara Kabupaten Ende.
\end{abstract}

\footnotetext{
"Alamat korespondensi:

Program Studi Pendidikan Guru Sekolah Dasar

Fakultas Keguruan dan Ilmu Pendidikan Universitas Flores

Kampus III Universitas Flores, Jln. Samratulangi,

Kelurahan Paupire, Ende, NTT

E-mail: $\underline{\text { arnestawende651@gmail.com }}$

() 2020 Program Studi PGSD Universitas Flores Email: primagistrauniflor@gmail.com
} 


\section{PENDAHULUAN}

Dalam situasi sekarang ini pendidikan merupakan salah satu unsur penting dalam pembangunan dan pengembangan bangsa Indonesia. Hal demikian tentunya tak terlepas dari peran pemerintah dalam dunia pendidikan untuk mengukur kemajuan suatu bangsa dengan bertumpu pada kekuatan sumber daya manusia. Kemajuan suatu bangsa mengharuskan suatu pendidikan yang berkualitas yang mana proses belajar mengajar dapat berlangsung secara efektif dan siswa mengalami proses pembelajaran yang bermakna. Sejalan dengan hal ini kemajuan pendidikan suatu bangsa mengharuskan adanya sumber daya manusia yang unggul di segala bidang kehidupan, sehingga banyak kemudahan di dalam dunia pendidikan.

Pokok-pokok pikiran tersebut akan membawa kita pada suatu kesimpulan dasar bahwa dalam masa sekarang ini guru atau calon guru perlu mempelajari pendidikan untuk membantu siswa belajar, meningkatkan kemampuan profesionalnya dan membantu aspek desain dan pelaksanaan penelitian pendidikan. Menurut Undang-Undang No.20 Tahun 2003 (Sanjaya, 2013: 2) tentang sistem pendidikan nasional menyatakan bahwa dalam pendidikan adalah suatu proses yang dilakukan dengan rancangan yang dilakukan secara sadar demi memperoleh keadaan, baik dalam belajar agar dalam pembelajaran siswa secara aktif dapat mengembangkan kemampuan dirinya untuk memperoleh nilai spiritual keagamaan, pengendalian diri, kepribadian, kecerdasan, akhlak mulia, serta kemampuan lain yang diperlukan bagi dirinya maupun masyarakat sekitar.

Berdasarkan Undang-undang tersebut sejauh ini pendidikan pada umumnya memiliki peranan yang sangat penting untuk menggali daya pikir siswa yang inovatif mengembangkan potensinya ketika berinteraksi di lingkungan. Sejalan dengan ilmu pengetahuan dan teknologi yang semakin berkembang pesat sangat mempengaruhi perkembangan pendidikan IPA terutama di negara-negara yang sudah maju. Dalam proses pembelajaran IPA tersebut seharusnya di sediakan serangkaian pengalaman berupa kegiatan nyata yang rasional atau dapat di mengerti oleh siswa dan memungkinkan terjadinya interaksi sosial. Jadi saat proses pembelajaran siswa harus terlibat secara aktif dalam kegiatan nyata. Untuk itu kita sebagai guru harus mempersiapkan pembelajaran yang melibatkan aktivitas siswa secara penuh dan siswa juga dituntut untuk menguasai materi dengan baik setelah pembelajaran IPA berlangsung.

Melalui pembelajaran IPA siswa dapat menemukan berbagai hal yang terjadi dalam kehidupan sehari-hari yakni seperti seperti kejadian-kejadian nyata yang ditemukan siswa. Pendidikan IPA dapat membantu untuk mengungkapkan secara sistematis dalam mencari tahu hal-hal yang terjadi serta dapat membentuk kepribadian atau tingkah laku siswa sehingga siswa dapat memahami proses IPA dan dikembangkan di masyarakat. Pendidikan IPA bukan hanya sekedar teori akan tetapi dalam setiap bentuk pengajaran lebih ditekankan pada bukti dan kegunaan ilmu tertentu.

Dalam pembelajaran IPA setelah guru menyampaikan materi pada siswa, maka guru dan siswa dapat membuat suatu presentasi praktek yang dilakukan untuk mempraktekan dan membuktikan materi yang telah di ajarkan dengan memilih metode pembelajaran yang tepat serta mempergunakan media yang mendukung sebagai sarana yang efektif. Dalam dunia pendidikan, pembelajaran IPA merupakan mata pelajaran yang hanya fokus dan mengandalkan kemampuan bernalar dan menggunakan logika yang baik. Oleh karena itu siswa diminta agar dalam dirinya harus menguasai rancangan serta gagasan IPA yang berkaitan dengan materi yang akan dipelajari.

Namun yang sering ditemukan yakni kemampuan siswa dalam belajar masih kurang, siswa juga cenderung pasif dalam proses pembelajaran yang monoton. Acapkali pola pembelajaran yang dipergunakan ialah ceramah dengan ciri guru menjadi pusat pembelajaran teacher centered, sebaliknya siswa hanyalah objek dari proses pembelajaran yang ada, sehingga para siswa lebih pasif bahkan memungkinkan kecenderungan antipati terhadap proses pembelajaran yang ada. Akibatnya siswa 
kurang berinisiatif untuk bertanya kepada guru tentang hal-hal yang belum di mengerti perihal materi yang diajarkan. Siswa juga sangat mudah melupakan materi yang sudah diberikan sehingga hasil belajar siswa rendah. Hasil belajar merupakan acuan untuk mengetahui sejauh mana tujuan pembelajaran itu tercapai

Gagne (Jufri, 2013: 58) menyatakan bahwa hasil belajar adalah suatu kemampuan (performance) yang dapat diamati dalam diri seseorang dalam memperoleh kepandaiannya dan disebut dengan kapabilitas, yang terdiri dari: keterampilan intelektual (intelektual skill), strategi kognitif (cognitive strategy), informasi verbal (verbal information), keterampilan motorik (motor skill), dan sikap (attitude).

Nawawi (Susanto, 2013: 5) menyatakan bahwa hasil belajar adalah perolehan hasil tes berupa skor dari seperangkat materi yang dipelajari untuk mengetahui tingkat keberhasilan siswa ketika mempelajari materi pembelajaran di sekolah. Dari pendapat diatas dapat dikatakan bahwa hasil belajar adalah perolehan keberhasilan dari pelaksanaan pembelajaran dalam kelas yang dapat membawa perubahan bagi siswa yang dapat dilihat dalam bentuk skor atau nilai baik dalam pengetahuan, sikap dan keterampilan sebagai hasil dari proses kegiatan belajar yang dilakukan.

Berdasarkan pengalaman dan praktik lapangan di SDI Tetandara terlihat secara jelas bahwa pembelajaran Ilmu Pengetahuan Alam belum dikembangkan dengan baik. Hal ini dibuktikan ketika observasi awal penelitian di sekolah tersebut. Pada observasi awal tersebut peneliti menemukan inti permasalahan yang mana dapat dikatakan demikian karena, proses pembelajaran pada materi tersebut terkesan hanya komunikasi searah. Dilihat dari tingkah laku siswa ketika pembelajaran IPA berlangsung dikelas ada beberapa kelompok siswa yang tidak memperhatikan dan mengacuhkan penjelasan dari guru, siswa lebih cenderung berbicara dengan temantemannya dibanding memperhatikan penjelasan dari guru didepan kelas. kurang fokusnya siswa pada pelajaran dipengaruhi oleh metode pembelajaran yang diterapkan di kelas.

Kurangnya variasi metode pembelajaran di kelas mempengaruhi minat belajar siswa dan aktivitas siswa. Sehingga berpengaruh pada rendahnya hasil belajar, khususnya pada pembelajaran IPA materi gerak benda. Nilai rata-rata yang diperoleh pada saat pra tindakan belum mencapai kriteria ketuntasan. dimana perolehan nilai rata-rata sebesar 48 dengan ketuntasan $25 \%$ dan yang tidak tuntas mencapai $75 \%$. Penggunaan metode pembelajaran yang tidak tepat akan mempengaruhi motivasi, aktivitas dan rendahnya hasil belajar. Selain metode ceramah, masih banyak metode pembelajaran lainnya yang bisa digunakan di kelas. Salah satunya adalah metode demonstrasi.

Metode demonstrasi menurut Suryani \& Agung (2012: 60) Metode demonstrasi adalah suatu hal yang dalam penyajian bahan ajar dengan contoh menunjukan kepada siswa tentang situasi yang terjadi pada hal-hal tertentu yang di pelajari berupa tiruan yang disertai dengan penjelasan. Dan menurut Husamah (2014) metode demonstrasi adalah metode yang dilaksanakan untuk menampilkan suatu proses, mekanisme atau cara kerja suatu alat yang berkaitan dengan materi pembelajaran.

Uno \& Mohamad (2013: 98) metode demonstrasi yaitu salah satu metode yang digunakan dalam proses pembelajaran aktif, sebab bersentuhan dengan bagaimana siswa memperagakan sesuatu, karena strategi pembelajaran ini memperlihatkan bagaimana ia melakukan sesuatu yang kemudian diamati dan dibahas. Dari uraian beberapa para ahli diatas, maka dapat disimpulkan bahwa "metode demonstrasi adalah metode yang dapat membantu siswa untuk mencari jawaban dengan usaha sendiri berdasarkan fakta yang benar dengan memperagakan kembali suatu yang telah disajikan".

Kelebihan metode demonstrasi menurut Majid (2015) metode demonstrasi menuntut 
siswa untuk aktif dalam pembelajaran, dalam hal ini siswa memperhatikan secara langsung bahan pelajaran yang dijelaskan secara langsung oleh guru, dengan demikian siswa dapat memiliki kemampuan untuk membandingkan antara teori dan kenyataan dan pada akhirnya siswa dapat meyakini kebenaran materi pembelajaran.

Berikut langkah-langkah metode demonstrasi menurut Majid (2015). Langkah Pertama biasa disebut sebagai tahap persiapan. Adapun hal yang perlu dilakukan antara lain adalah merumuskan tujuan pembelajaran yang harus dicapai setelah proses demonstrasi berakhir, menyiapkan garis besar langkah-langkah demonstrasi yang akan dilakukan, melakukan uji coba demonstrasi.

Langkah kedua disebut sebagai tahap pelaksanaan. Sebelum demonstrasi dilakukan ada beberapa hal yang harus diperhatikan yaitu: (1) mengatur tempat duduk yang memungkinkan semua dapat memperhatikan dengan jelas apa yang didemonstrasikan; (2) mengemukakan tujuan yang harus dicapai oleh siswa; (3) mengemukakan tugas apa yang harus dilakukan oleh siswa misalnya siswa ditugaskan mencatat hal-hal yang dianggap penting dari pelaksanaan demonstrasi.

Adapun langkah-langkah pelaksanaan demonstrasi adalah sebagai berikut: (1) mulailah demonstrasi dengan egiatan-kegiatan yang merangsang siswa untuk berfikir, misalnya melalui pertanyaan yang mengandung teka-teki sehingga siswa tertarik memperhatikan proses demonstrasi; ciptakan suasana yang menyejukan dengan menghindari suasana yang menegangkan. Apabila demonstrasi telah swlwsai dilakukan proses pembelajaran diakhiri dengan memberikan tugas-tugas tertentu yang ada kaitannya dengan pelaksanaan demonstrasi dan proses pencapaian tujuan pemebelajaran serta melakukan evaluasi bersama tentang jalannya proses demonstrasi untuk perbaikan selanjutnya.

Berdasarkan penjelasan metode demonstrasi tersebut dan bila dikaitkan dengan materi gerak benda pada siswa kelas III metode pembelajaran tersebut bisa dijadikan acuan bagi peningkatan hasil belajar siswa, khususnya hasil belajar IPA.

Metode demonstrasi dapat membantu siswa untuk mencari jawaban dengan usaha sendiri berdasarkan fakta yang benar dengan memperagakan kembali sesuatu yang telah disajikan. Dengan demikian materi gerak benda merupakan materi yang cocok bila diterapkan metode demonstrasi pada proses pembelajarannya, karena siswa secara langsung melibatkan diri dalam menemukan berbagai fakta melalui apa yang ia peragakan dan demonstrasikan.

Atas dasar nilai lebih yang dimiliki dari metode pembelajaran ini dan permasalahan yang dihadapi pada sekolah tersebut, maka peneliti melakukan penelitian menggunakan metode demonstrasi untuk mengatasi permasalahan hasil belajar IPA pada siswa kelas III di SDI Tetandara Kabupaten Ende.

\section{METODE PENELITIAN}

Jenis penelitian yang digunakan adalah Penelitian tindakan kelas (PTK). Menurut Wardhani \& Wihardit (2011: 4) Penelitian tindakan kelas adalah suatu penelitian yang dicapai dengan tujuan untuk memperbaiki kinerja guru sebagaimana dapat menjadikan hasil belajar siswa menjadi meningkat. Penelitian tindakan kelas ini menggunakan pendekatan kualitatif. Menurut Sugiyono (2016: 15) pendekatan kualitatif adalah pendekatan yang berlandaskan pada filsafat postpositivisme, pada obyek yang diteliti secara alamiah, dimana peneliti sebagai instrumen kunci. Teknik pengumpulan data bersifat trianggulasi yaitu menggunakan berbagai teknik pengumpulan data secara gabungan. Penelitian kualitatif ini lebih cenderung pada suatu makna dari pada generalisasi.

Waktu penelitian ini dilaksanakan pada tanggal 18 sampai 31 Mei 2019 Tahun Pelajaran 2019/2019. Tempat penelitian di SDI Tetandara, Kecamatan Ende Tengah Kabupaten Ende. Target atau sasaran dalam penelitian ini ialah hasil belajar IPA dengan menggunakan metode Demonstrasi. Subjek dalam penelitian ini adalah 20 orang siswa kelas III SDI Tetandara Kecamatan Ende Tengah Kabupaten Ende. 
Prosedur penelitian menggunakan penelitian tindakan kelas, dimana subyek yang diteliti adalah masalah yang terdapat di dalam kelas. Arikunto (Suyadi, 2012: 49) Secara umum mengatakan bahwa terdapat empat langkah dalam melakukan penelitian tindakan kelas, yaitu perencanaan, pelaksanaan, pengamatan, dan refleksi". Penelitian tindakan kelas juga terbagi dalam beberapa siklus penelitian. Jika dalam penelitian tindakan kelas terdapat lebih dari satu siklus, maka siklus kedua dan seterusnya merupakan putaran ulang dari tahapan sebelumnya.

Data yang dikumpulkan dalam penelitian ini adalah hasil observasi aktivitas guru dan siswa pada siklus I dan II serta hasil belajar IPA siswa kelas III pada siklus I dan siklus II. Data yang dianalisis adalah data yang diambil pada saat pembelajaran berlangsung. Analisis data hasil penelitian dilakukan dengan dua teknik penilaian yakni: (1) Penilaian Sikap/Lembar observasi perilaku; (2) Penilaian ketuntasan hasil belajar. Ketuntasan belajar ada dua kategori, yaitu: ketuntasan perorangan (ketuntasan individu) dan ketuntasan rata-rata kelas (ketuntasan klasikal).

Analisis data hasil observasi aktivitas guru pelaksana tindakan, dan observasi siswa, yang diperoleh dari hasil pengamatan observer, mengikuti petunjuk menurut (Jihad dan Haris, 2012: 130), pada format penilaian sikap (selama proses pembelajaran), kolom perilaku diisi dengan angka yang sesuai dengan kriteria

Tabel 1. Kolom kriteria perilaku

\begin{tabular}{cc}
\hline Angka & Kriteria \\
\hline 1 & Sangat kurang \\
2 & Kurang \\
3 & Cukup \\
4 & Baik \\
5 & Sangat baik \\
\hline
\end{tabular}

$$
\text { Nilai }=\frac{\text { skor perolehan }}{\text { skor maksimum }} \times 100
$$

Kolom kriteria diisi sesuai dengan tabel 2 berikut ini:

\begin{tabular}{cl} 
Tabel 2. Kolom Klasifikasi kriteria perilaku \\
\hline Konversi nilai & \multicolumn{1}{c}{ Klasifikasi } \\
\hline $0-20$ & Sangat kurang \\
$21-40$ & Kurang \\
$41-60$ & Cukup \\
$61-80$ & Baik \\
$81-100$ & Sangat baik \\
\hline
\end{tabular}

\section{Ketuntasan Individu}

Untuk menentukan ketuntasan belajar siswa dapat digunakan rumus sebagai berikut :

$$
\begin{aligned}
& \mathrm{KB}=\frac{T}{T t} \times 100 \\
& \text { (Trianto,2011: .63) }
\end{aligned}
$$

\section{Ketuntasan Klasikal}

Untuk menghitung persentase ketuntasan belajar klasikal, digunakan rumus sebagai berikut :

$$
\mathrm{P}=\frac{\text { Esiswa yang tuntas belajar }}{\begin{array}{c}
\text { Esiswa } \\
\text { (Daryanto, 2011: 192) }
\end{array}} \times 100 \%
$$

Analisis ini dilakukan pada saat tahapan releksi. Hasil analisi ini digunakan sebagai bahan refleksi untuk melakukan perencanaan lanjut dalam siklus selanjutnya. Kriteria tingkat keberhasilan belajar siswa dalam \% diuraikan dalam tabel berikut :

Tabel 3. Kriteria Tingkat Keberhasilan Belajar Siswa dalam \%

\begin{tabular}{cc}
\hline $\begin{array}{c}\text { Tingkat Keberhasilan ( } \\
\%)\end{array}$ & Arti \\
$\geq 80 \%$ & Sangat tinggi \\
$69-79 \%$ & Tinggi \\
$40-59 \%$ & Sedang \\
$20-39 \%$ & Rendah \\
$\leq 19 \%$ & Sangat rendah \\
\hline
\end{tabular}

Pembelajaran dengan menggunakan metode demonstrasi dikatakan efektif meningkatkan hasil belajar IPA, jika hasil belajar siswa $\geq 70$, dengan persentase ketuntasan klasikal sekurang-kurangnya $80 \%$.

\section{HASIL DAN PEMBAHASAN}

\section{A. Hasil Penelitian}

Tujuan dari penelitian ini adalah untuk meningkatkan hasil belajar pada pembelajaran IPA melalui metode demonstrasi pada siswa kelas III SDI Tetandara. Hasil penelitian dapat dilihat pada tabel 1 berikut ini

Tabel 4. Nilai hasil belajar IPA

\begin{tabular}{ccccc}
\hline No & $\begin{array}{c}\text { Nilai hasil } \\
\text { belajar }\end{array}$ & $\begin{array}{c}\text { Pra } \\
\text { Siklus }\end{array}$ & Siklus I & $\begin{array}{c}\text { Siklus } \\
\text { II }\end{array}$ \\
\hline 1 & Rata-rata & 48 & 57 & 84,5 \\
2 & Tuntas & $25 \%$ & $35 \%$ & 100 \\
3 & Tidak Tuntas & $75 \%$ & $65 \%$ & - \\
\hline
\end{tabular}

Berdasarkan data pada Tabel 4, diketahui bahwa persentase ketuntasan belajar sebelum 
diberi tindakan sebesar $25 \%$ dengan nilai ratarata sebesar 48. Pada siklus I mengalami sedikit peningkatan yaitu $35 \%$ dengan nilai rata-rata sebesar 57. Berkaca pada hasil siklus I, maka penelitian dilanjutkan sampai siklus II.

Pada siklus II, nilai rata-rata kelas meningkat menjadi 84,5 dengan persentase ketuntasan sebesar $100 \%$. Hasil pada siklus II sudah memenuhi target yang ingin dicapai yaitu $\geq 70$. Dengan demikian penelitian dengan menggunakan metode demonstrasi telah berhasil meningkatkan hasil belajar IPA pada siswa kelas III di SDI Tetandara Kabupaten Ende.

\section{B. Pembahasan}

Penelitian tindakan kelas ini melalui empat tahapan tahapan yang pertama adalah tahap perencanaan. Pada tahap perencanaan, peneliti menyiapkan perangkat pembelajaran seperti menyiapkan materi tentang gerak benda, menyiapkan RPP, menyiapkan alat dan bahan sesuai dengan materi, menyusun lembar kerja siswa, dan menyusun evaluasi pembelajaran.

Tahap kedua adalah tahap pelaksanaan tindakan. Penelitian ini dilaksanakan mulai hari Rabu 22 Mei 2019. Peneliti melakukan penelitian di SDI Tetandara dengan menggunakan metode demonstrasi dengan berpedoman pada rencana pelaksanaan pembelajaran (RPP) yang telah disiapkan.

Tahap ketiga, yaitu tahap observasi, pada tahap ini para peneliti bersama guru melakukan kegiatan pengamatan sesuai dengan lembar observasi yang sudah disiapkan pada tahap perencanaan.

Tahap berikutnya adalah tahap refleksi pada tahap ini kegiatan refleksi dilakukan berdasarkan hasil evaluasi dan dari hasil observasi. Berdasarkan hasil evaluasi, diketahui bahwa pada siklus I, hasil belajar dari sebagian besar siswa belum mencapai KKM 70. Dari 20 orang siswa hanya 7 orang yang tuntas, sedangkan 13 orang lainnya tidak tuntas. Hal ini menunjukan bahwa masih banyak siswa belum terlalu memahami materi pembelajaran dengan baik
Pada siklus I peneliti menemukan bahwa ada beberapa kelemahan-kelemahan yang harus diperbaiki yaitu: (1) Guru kurang memunculkan permasalahan pada metode demonstrasi. (2) Guru kurang membimbing siswa baik individu maupun kelompok dalam mengikuti pembelajaran (3) Guru kurang memberikan kesempatan kepada siswa untuk menjawab pertanyaan serta kurangnya motivasi yang diberikan guru pada siswa. Berdasarkan hasil refleksi tersebut maka penelitian dilanjutkan ke siklus berikutnya.

Langkah-langkah pada siklus II dilakukan sama seperti pada siklus I, mulai dari tahap perencanaan, pelaksanaan, observasi dan refleksi. Namun kegiatan pada siklus II ini dilakukan berdasarkan hasil refleksi pada siklus I. Hasil pada siklus II menunjukkan bahwa terdapat perubahan hasil belajar yang signifikan pada siklus II. Dimana pada siklus ini hasil belajar meningkat dengan nilai ratarata sebesar 84,5 dengan persentase ketuntasan sebesar $100 \%$.

Pencapaian ini disebabkan karena peneliti sudah menerapkan pembelajaran menggunakan metode demonstrasi dengan baik langkah-langkah pembelajaran melalui metode ini sudah dilakukan secara runtut dan guru sudah lebih memperhatikan siswa dengan membimbing dan memberi kesempatan pada setiap anak untuk bertanya dan mengutarakan pendapatnya. Guru juga sudah banyak memberikan motivasi pada siswa. Hal ini dapat dilihat pada Gambar 1 dan Gambar 2 berikut ini:

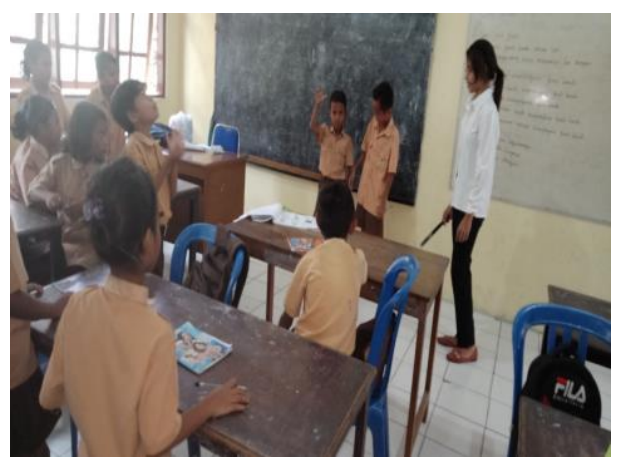

Gambar 1. Siswa mendemonstrasikan berat ringan benda mempengaruhi gerak benda. 


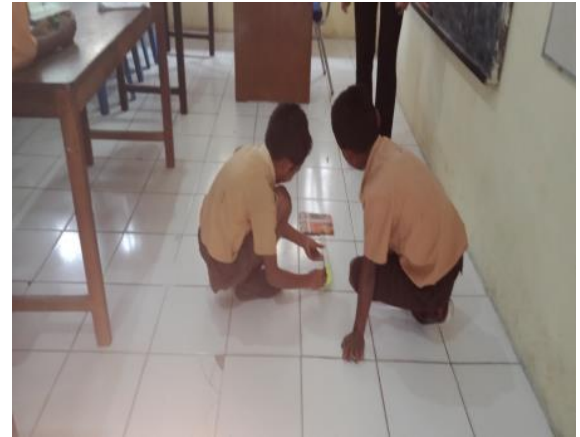

Gambar 2. Siswa mendemonstrasikan keadaan permukaan lintasan benda mempengaruhi gerakan benda.

Mencermati hasil penelitian diketahui bahwa hasil belajar siswa di SDI Tetandara sudah mencapai keberhasilan sesuai yang diharapkan. Hal ini dapat dilihat dari rata-rata kemampuan siswa pada siklus I dan siklus II.

Persentase ketuntasan belajar pada siklus I sebesar 35\% meningkat menjadai $100 \%$ pada siklus II dengan Nilai rata-rata sebesar 84,5.Dari data yang diperoleh tersebut, menunjukan bahwa dalam penggunaan metode demonstrasi pada materi gerak benda dapat meningkatkan hasil belajar siswa kelas III di SDI Tetandara. Berdasarkan uraian diatas dapat ditampilkan data peningkatan hasil belajar siswa pada pembelajaran siklus I dan siklus II pada grafik di bawah ini.

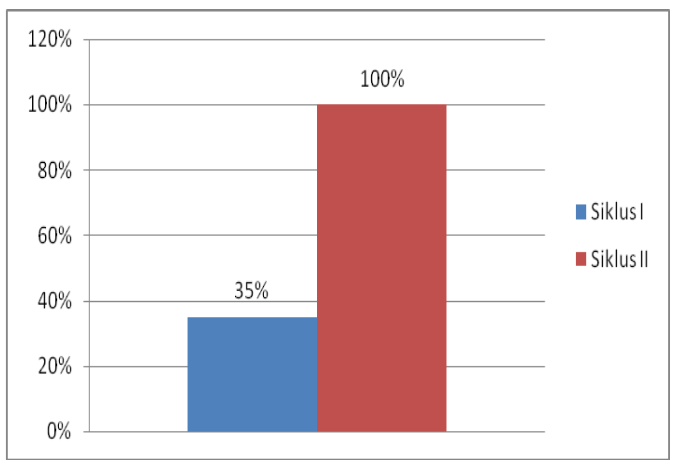

Gambar 3: Perbandingan ketuntasan klasikal Siklus I dan Siklus II

Berdasarkan hasil yang dicapai pada siklus II, Maka penelitian tentang penggunaan metode demonstrasi untuk meningkatkan hasil belajar IPA pada siswa kelas III di SDI Tetandara, tidak dilanjutkan ke siklus berikutnya, karena hasil yang di dapat sudah mencapai target yang diharapkan. Hasil belajar siswa sudah memenuhi KKM $\geq 70$ dengan ketuntasan klasikal 100\%.

\section{SIMPULAN DAN SARAN}

Berdasarkan hasil penelitian dan pembahasan, dapat disimpulkan bahwa penggunaan metode demonstrasi dapat meningkatkan hasil belajar IPA materi gerak benda pada siswa kelas III di SDI Tetandara. Hasil belajar siswa mengalami peningkatan yaitu pada siklus I rata-rata 57 dengan persentase ketuntasan mencapai $35 \%$ dan siklus II rata-rata 84,5 dengan persentase ketuntasan mencapai $100 \%$.

Dari hasil tersebut, saran peneliti bagi guru IPA di SD, adalah agar dalam menyiapkan perangkat pembelajaran harus memilih metode yang sesuai dengan materi yang akan diajarkan dan menyiapkan perangkat pembelajaran dengan metode yang dipilih sebaik mungkin, agar tujuan pembelajaran yang ingin dicapai dapat terwujud.

\section{DAFTAR PUSTAKA}

Daryanto. 2011. Penelitian Tindakan Kelas dan Penelitian Tindakan Sekolah. Yogyakarta: Gaya Media.

Husamah. 2014. Pembelajaran Bauran (Blended Learning). Jakarta : Pustakarya.

Jihad \& Haris. 2012. Evaluasi Pembelajaran. Yogyakarta : Multi Pressindo.

Jufri,Wahab. 2013. Belajar dan Pembelajaran SAINS. Bandung : Pustaka Reka Cipta.

Majid, Abdul. 2015. Perencanaan Pembelajaran. Bandung: PT. Remaja Rosdakarya.

Ranya, Zulham A. 2013. Meningkatkan Hasil Belajar Siswa dalam Pembelajaran IPA Pokok Bahasan Panca Indra dengan Menggunakan Metode Demonstrasi Pada Siswa Kelas IVA SDN 5 Pusungi. Jurnal Kreatif Tadulako, Vol 1 No 2. http://jurnal.untad.ac.id/jurnal/index.php /JKTO/article/view/2671

Sugiyono. 2016. Metode Penelitian Pendidikan. Bandung : Alfabeta.

Suryani, Nunuk. \& Agung Leo. 2012. Strategi Belajar Mengajar. Yogyakarta : Ombak. 
Susanto, A.2013. Teori Belajar \& Pembelajaran. Jakarta : Kencana.

Suyadi. 2012. Panduan Penelitian Tindakan Kelas. Jogjakarta : Diva Press.

Trianto. 2011. Panduan Lengkap Penelitian Tindakan Kelas. Jakarta : Prestasi Pustakaraya.

Uno,H.B. \& Mohamad Nurdi.2013. Belajar dengan pendekatan PAILKEM. Jakarta : Bumi Aksara.

Wihardit,Kuswaya \& Whardhani.2011. Penelitian Tindakan Kelas. Jakarta : Universitas Terbuka .

Sanjaya, Wina. 2013 Penelitian Pendidikan, Jenis, Metode dan Prosedur. Jakarta: Kencana Prenada Media Group 